International Business Management 4 (2): 67-75, 2010

ISSN: $1993-5250$

(C) Medwell Journals, 2010

\title{
Is Entrepreneurial Competency the Silver Bullet for SME Success in a Developing Nation?
}

\author{
Noor Hazlina Ahmad, Hasliza Abdul Halim and Siti Rohaida Mohamed Zainal \\ School of Management, University Sains Malaysia, 11800 Penang, Malaysia
}

\begin{abstract}
This study proposed the direct relationship between entrepreneurial competency and business success in SMEs by taking into consideration the various roles held by entrepreneurs in managing their own ventures. Evidence suggests that entrepreneurs, especially in SMEs engage in various tasks that demand possession of relevant competencies to enable them manage their ventures effectively. Linking the roles of entrepreneurs as identified in the literature namely entrepreneurial, managerial and functional roles with the competencies required in handling successful ventures, a conceptual framework is advanced for further empirical investigation. Propositions are made by integrating the roles of entrepreneurs in examining the relationship between entrepreneurial competencies and business success in SMEs. The suggested model of entrepreneurial competencies is intended for use by business practitioners, trainers and educators in efforts to develop the right mix of competencies in generating more successful ventures in SMEs.
\end{abstract}

Key words: Entrepreneurial competency, SME success, developing nation, mange, Malaysia, business

\section{INTRODUCTION}

In recent times, SMEs especially in the emerging economies are struggling to navigate the current rough economic ocean. Debates are going on among scholars, practitioners and policy makers to identify a model to assist SMEs to sail smoothly through the stretch of hurdles. Reflecting on Gibb(2005)'s contention pertaining to the significant role of SME entrepreneurs in managing their ventures, some insights into how to increase the odds of survival and success among SMEs could possibly be unearthed.

In essence, calls to refocus on the key roles of the entrepreneurs open up rooms for further deliberation on the requisite competencies that can be ingrained to cushion the adverse economic impact among SMEs. Based on the Theory of Entrepreneurial Competency proposed by Bird (1995), this study posits that competency model could shed some light into ways to increase the likelihood of business survival and success especially in the context of a developing country like Malaysia.

SMEs in Malaysia: The focus on SMEs in Malaysia is based on the importance of SMEs to the country's economy. SMEs have been acknowledged as the strategic thrust in Malaysia economy based on various reports of government agencies. The definition of SMEs in the context of Malaysia is shown in Table 1. The contribution of SMEs to the country's GDP, employment and export demonstrated the important contribution of this sector to the economic well-being of the country (Fig. 1).

To further galvanise this sector, Malaysian government has provided a variety of support mechanism especially in terms of training programs, funding and grants sadly however, many SMEs still fail. This has prompted a greater scrutiny to delve into the possible panacea for this problem. The contention of this study is similar to that of Gibb (2005) in which the focus should now be on the key roles played by the SME entrepreneurs as well as the key competencies required to successfully engage in these roles.

The concept of competency is not new to the management field. Building upon the research of Mintzberg (1973) that identifies ten important roles of managers, management scholars have further investigated the competencies associated with these roles which could lead to superior performance in organisation.

Some studies have noted the importance of understanding an individual's job roles in exploring competencies associated with each role (Spencer and Spencer, 1993). In view of this, it is believed that by understanding the roles of entrepreneurs better insights into the competencies needed for business survival and success in SMEs could be generated. Researchers have

Corresponding Author: Hasliza Abdul Halim, School of Management, University Sains Malaysia, 11800 Penang, Malaysia 
Table 1: Definition of SMEs in Malaysia

\begin{tabular}{|c|c|c|c|}
\hline Defination of SMEs & Micro-enterprise & Small enterprise & Medium enterprise \\
\hline $\begin{array}{l}\text { Manufacturing, Manufacturing-related } \\
\text { servirce and agro-based industries }\end{array}$ & $\begin{array}{l}\text { Sales tumover of }<\text { RM } 250,000 \\
\text { OR full time employees }<5\end{array}$ & $\begin{array}{l}\text { Sales turnover between RM250,000 } \\
\text { and }<\text { RM10 OR full time employees } \\
\text { between } 5 \text { and } 50\end{array}$ & $\begin{array}{l}\text { Sales tumover between RM10 million } \\
\text { and RM25 million OR full time } \\
\text { employees between } 51 \text { and } 150\end{array}$ \\
\hline $\begin{array}{l}\text { Services, Primary Agriculture and } \\
\text { Information and Communication } \\
\text { Technology (ICT) }\end{array}$ & $\begin{array}{l}\text { Sales turnover of }<\text { RM } 200,000 \\
\text { OR full time employees }<5\end{array}$ & $\begin{array}{l}\text { Sales turnover between RM200,000 } \\
\text { and }<\text { RM1 million OR full time } \\
\text { employees between } 5 \text { and } 19\end{array}$ & $\begin{array}{l}\text { Sales tumover between RM1 million } \\
\text { and RM5 million OR full time } \\
\text { employees between } 20 \text { and } 50\end{array}$ \\
\hline
\end{tabular}

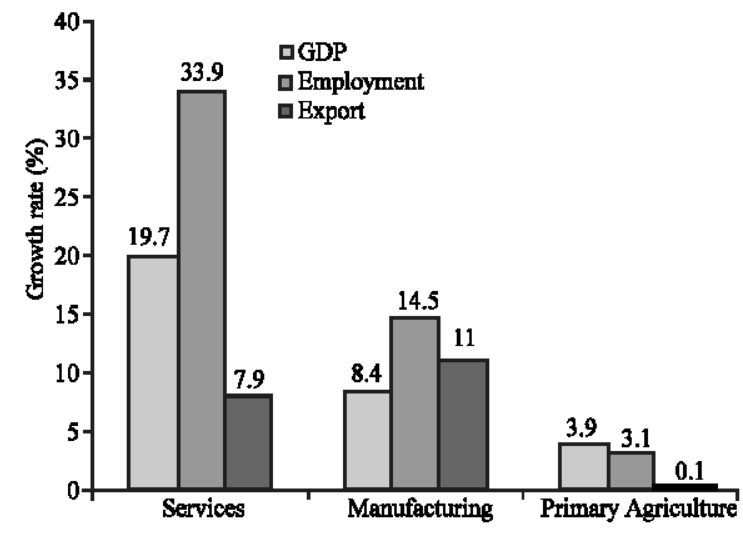

Fig. 1: Contribution of SMEs to gross domestic product, employment and export by sector in 2005

reached to a consensus on the fact that entrepreneurs operating in SMEs assume complex and challenging tasks which require them to engage in several different roles. Among the most important roles played by entrepreneurs are entrepreneurial role, managerial role (Beaver and Jennings, 2005; Chandler and Jansen, 1992) and functional roles (Chandler and Jansen, 1992).

Accordingly, being engaged in each role demands possession and application of certain skills and abilities (competencies) among entrepreneurs. Following this logic, entrepreneurs must equip themselves with competencies that allow them to perform effectively in their business, which may subsequently lead to business success.

The roles of SME entrepreneurs: In SMEs, the critical resources are likely to be held by the individual entrepreneurs that are reflected in their skills, knowledge, abilities, experience and education (Edelman et al., 2002). Being the key decision makers, the entrepreneurs have high influence on the formation of business strategy and are responsible to set the roadmap for their firms to move towards the set goals (Masurel et al., 2003). The lack of separation between ownership and control in small firms suggests that the business owners themselves are responsible for the direction and the development of their firms (Yu, 2001). Various studies have confirmed that the person who forms a venture is ultimately responsible for its success or failure (Hall and Fulshaw, 1993; Shane and Venkataraman, 2000). To put it differently, a proposition has been made that in order to understand why organization fail, researchers should focus on the actions of the top management (Longenecker et al., 1999) in which in the case of SMEs, refers to the entrepreneurs themselves. Hence, the success or failure of the firms is largely influenced by the skills and abilities (or competencies) of the owners. Thus as key players, the ability of entrepreneurs to cope with all responsibilities (as shown in their competencies) that come along with these roles-entrepreneurial, managerial and functionalshould not be overlooked.

Entrepreneurial role: Engaging in entrepreneurial role involves performing activities such as developing challenging but achievable vision, formulating strategies, perceiving unmet consumer needs, scanning the environment, spotting high quality opportunities and producing superior products or services (Chandler and Hanks, 1994; Chandler and Jansen, 1992). These roles require entrepreneurs alertness, innovativeness and creativity (Thompson, 1999), strong commitment (Man and Lau, 2000) and conceptual ability to seek, identify, assess and seize opportunities and transmute them into profitable outcome (Thompson et al., 1997).

Thompson (1999) maintained that an entrepreneur is someone with a vision who spots a new opportunity and is minded to act on it and start something and enterprising behaviour relates to starting a new venture which requires setting out ideas obtaining resources and making things happen. Extending this view, it has been suggested that the ability to select high quality opportunities and devise appropriate strategies to turn these opportunities into reality may have a considerable impact on venture performance (Wang and Ang, 2004).

Furthermore, engaging in entrepreneurial role demands entrepreneurs to continually seek out customer needs and find ways to offer their product and services in such a way that what they are offering is more attractive than others (Tracy, 2005). This requires ability to use appropriate strategies and tactics in commercialising their 
products or services. Entrepreneurs must also be willing to experiment different strategies in the pursuit of profitable outcome because it is the entrepreneurs energy, creativity and motivation that trigger the production of superior product and services (Baum and Locke, 2004). Thus, it is proposed that engaging in entrepreneurial role requires entrepreneurs to equip themselves with relevant competencies that will increase the odds of their business success.

Managerial role: As the owner-managers who have the overall control of the firms, entrepreneurs especially in SMEs are required to take up managerial role. Managerial tasks reflect activities such as planning, organizing, directing and controlling various resources in organization. These functions are said to be goal-directed, interrelated and interdependent.

Planning, for example, involves devising a systematic process for attaining the goals of the organization and organizing involves arranging the necessary resources to carry out the plan (Chandler and Hanks, 1994). These resources include people, technology, facilities and equipment, materials and supplies information and money. Directing generally involves guiding, leading and overseeing of employees to achieve organizational goals, while controlling involves verifying that actual performance matches the plan.

In many ways, engaging in managerial role requires interpersonal skills such as establishing relationship and interacting with others. For example, the classic managerial role proposed by Mintzberg (1973) specifies figurehead, leader, liaison, disseminator, spokesperson, disturbance handler and negotiator as roles that are critical for managers. These roles obviously require abilities in relationship building and interpersonal communication with people within or outside the organization.

Chandler and Hanks (1994) argue that engaging in managerial role requires entrepreneurs to lead and motivate employees, delegate tasks and manage employee relations, which clearly requires good interpersonal skills on the part of the entrepreneurs. In sum, the ability to organize and build relationship is related to managerial role. It is therefore argued that engaging in managerial role requires entrepreneurs to equip themselves with appropriate competencies that will enhance the possibility of business success.

Functional role: As business owners, SME entrepreneurs are also engaged in functional role. Assuming this role requires possession of technical knowledge and procedures relevant to specific field and also the ability to utilise tools (Chandler and Jansen, 1992). The importance of having technical capabilities in conducting business has been highlighted in many studies (Baum, 1995; Winterton, 2002) suggesting that possessing specific skills in job-related activities is a vital requirement for entrepreneurs. Practically in SMEs, training employees internally would incur less cost compared to sending staff for external training courses.

In this sense, technical competencies are required so as to facilitate entrepreneurs in handling business-related tasks which require specific expertise and also in training the employees on tasks relevant to the business. Therefore, it is proposed that engaging in functional role requires entrepreneurs to equip themselves with relevant competencies that will increase the likelihood of their business success.

\section{MATERIALS AND METHODS}

Entrepreneurs competencies: Being engaged in various roles including entrepreneurial, managerial and functional roles, demand entrepreneurs to take up tasks and activities that are far more complex than those of managers employed in organizations.

The complexity of tasks perform by entrepreneurs suggests that it is vital to investigate further the forms of competencies that could increase the chances of success in SMEs.

Investigating further the important competencies relevant to entrepreneurs is also considered an effort to address issue on the unacceptably high failure rates reported among SMEs. This problem, unless addressed would negatively affect the socio-economic aspect of a country and the well being of the business owners themselves.

Competencies are underlying characteristics such as generic and specific knowledge, motives, traits, selfimages, social roles and skills which result in venture birth, survival and/or growth (Bird, 1995). Similarly, Baum et al., 2001 define competencies as individual characteristics such as knowledge, skills and/or abilities required to perform a specific job.

By incorporating the findings of mainly Man (2001) and a qualitative research of Ahmad and Seet (2009) together with a few other similar research, an analysis is developed to identify the competencies that can be linked to the role played by SME entrepreneurs. A critical analysis conducted on the earlier models of entrepreneurial competencies ultimately generated eight significant competencies that are recommended for further 
Table 2: Entrepreneurial competency domain

\begin{tabular}{|c|c|}
\hline $\begin{array}{l}\text { Entrepreneurial } \\
\text { competency domain }\end{array}$ & Examples of behaviours \\
\hline Strategic & $\begin{array}{l}\text { Set challenging but achievable business goals } \\
\text { and vision; devise strategies to achieve goals; } \\
\text { diagnose the effectiveness of strategies and } \\
\text { takecorrective action when necessary make } \\
\text { strategic change and use tactics in business }\end{array}$ \\
\hline Commitment & $\begin{array}{l}\text { Sustain effort; commit to long-term goals; } \\
\text { commit to personal goals and restart after failure }\end{array}$ \\
\hline Conceptual & $\begin{array}{l}\text { Think intuitively and quickly when making } \\
\text { decision view from different angle; innovate; } \\
\text { assess risks }\end{array}$ \\
\hline Opportunity & Identify, assess and seek business opportunities. \\
\hline Organizing and Leading & $\begin{array}{l}\text { Plan, organize, lead, motivate, delegate and } \\
\text { control }\end{array}$ \\
\hline Relationship & $\begin{array}{l}\text { Build relationship and network; communicate; } \\
\text { negotiate; manage conflict effectively }\end{array}$ \\
\hline Personal & $\begin{array}{l}\text { Personal qualities include self-confidence; self- } \\
\text { awareness; self-motivation; persistence; self- } \\
\text { management; positive mindedness }\end{array}$ \\
\hline Technical & $\begin{array}{l}\text { Handle tools and equipment relevant to } \\
\text { business; expertise in business-related areas }\end{array}$ \\
\hline
\end{tabular}

investigation which include strategic, conceptual, opportunity, organizing, relationship, technical and personal competencies (Table 2).

Strategic competency: Strategic competency involves strategic thinking which reflects the ability of the organization's leader to develop future vision and take strategic action which requires them to think beyond day-to-day operations (Stonehouse and Pemberton, 2002). Having this vision allows entrepreneurs to focus their actions and decisions more strategically and when achieved will give their firms significant advantages over the competitors. Also by having a set of clear goals and an overall picture of where and how the firm is going to compete entrepreneurs are able to formulate appropriate strategies and implement them to achieve the preset goals. These strategies serve as a bridge that links firms resources and their capabilities to gain competitive advantage Fand to overcome organizational uncertainty (Parnell et al., 2000). Operating in a dynamic environment often results in misfit between firms strategies and external demand which in turn impel organizations to strategically change their operations and restructure their business when necessary. As such, the ability to make strategic change also allows entrepreneurs to adapt and adjust the business operations to match the current demand in the industry.

Conceptual competency: Conceptual competency is related to the ability to think out of the box which is often reflected in the ability to stimulate new thinking patterns and develop new ideas and concepts which may sometimes require deviation from the normal procedure of doing things (Michalko, 2000). This ability allows entrepreneurs to do things differently take on new perspectives create value in new ways as well as focus on finding new ideas and act on them (Thompson et al., 1997). The ability to think analytically and to cope with uncertainty depends heavily on conceptual abilities (Bird, 1995). According to Man and Lau (2000), conceptual competency reflects the conceptual abilities of entrepreneurs such as analysing, problem solving, decision-making, innovating and risk taking. Conceptual competency also reflects the mental ability to coordinate all of the organization's interests and activities (Chandler and Jansen, 1992). More often than not, entrepreneurs are regarded as people whom creatively create new products, new services, new organizations and new ways of satisfying customers and doing business (Thompson, 1999). Being creative, innovative and flexible especially in dealing with opportunities, risks and uncertainties illustrate the important capabilities which enable entrepreneurs to make a difference (Thompson, 1999). Entrepreneurs especially those operating in the SME context, face numerous situations that require them to make quick decisions, therefore having the abilities to undertake high level of conceptual activities are important for the success and survival of their business.

Opportunity competency: One aspect of entrepreneurial role is the ability to recognise and taking advantage of opportunities. This competency is also associated with the ability of entrepreneurs to seek, develop and assess high quality opportunities that are available in the market (Man, 2001). The recognition of high quality opportunities prompts entrepreneurs to create organizations and embrace considerable risks to turn these opportunities into positive outcome. It was revealed that an important competency requirement for growing companies is the readiness to seize relevant opportunities (Snell and Lau, 1994). Entrepreneurs are also required to engage in a continuous search for products and services that could add value for the buyers or end users because the decision to exploit the opportunities depends on the entrepreneurs knowledge of customer demand (Choi and Shepherd, 2004).

Organizing and leading competency: Being the owner of a business, entrepreneurs are required to take up a variety of tasks and handle different functional areas which demand the ability to plan and organize various resources in the organization (Chandler and Hanks, 1994). McClelland (1987) suggests that monitoring is essential in keeping the firm operating efficiently, suggesting that business owners should be able to monitor closely their 
business activities so that activities are appropriately carried out. In addition, the management of human resources in SME is reported as distinctive activities which require entrepreneurs to equip themselves with organizing skills especially leading, delegating, couching and training (Martin and Staines, 1994).

In most SMEs, business owners have to deal directly with the employees and in many cases, there is no specific unit to administer employees as undertaken by human resources department in large firms. As such, possessing the ability to organize and lead would enable entrepreneurs to minimize the staggering rate of failures among SMEs.

Relationship competency: In business, entrepreneurs are required to deal with a lot of people including suppliers, customers, employees, government authorities, competitors and other stakeholders. Being in contact with a diverse set of individuals is important for entrepreneurs because it gives them access to information and other resources (Jenssen and Greve, 2002).

In doing so, entrepreneurs need to have good relationship competency to enable them to advance in their business. This is in line with resource dependency theory (Barringer and Harrison, 2000) which suggests that entrepreneurs use their social relations to get the resources they need to launch a business (Hansen, 2001; Jenssen, 2001).

Evidence suggests that small firms are engaged in networks especially in gaining advice and support from professionals and experts such as lawyers, accountants and consultants (Ramsden and Bennett, 2005) as well as government bodies, research and training institutes and even suppliers and customers (Ritter and Gemunden, 2004). To successfully secure business dealings with customers and suppliers, entrepreneurs engage in relationship building activities which are referred to as entrepreneurial bonding that reflects establishing and restructuring relationships with the most important stakeholders such as customers and suppliers as the company grow (Bird, 1995).

Technical competency: Technical competency includes the ability to use and adopt technical skills including the techniques and tools handling which are relevant to the business (Martin and Staines, 1994). This involves possessing knowledge of instruments and the functioning of tools, machines or research procedure as well as mastery of tasks or content of work.

It has been proposed that engaging in functional role, entrepreneurs require technical competency to ensure that business-related tasks could be accomplished satisfactorily (Chandler and Hanks, 1994). Baum (1995) has endorsed this by suggesting that that technical skill is an important requirement for entrepreneurs to create successful ventures. It has been further argued that it is crucial for entrepreneurs to have know-how (technical skill) and know that (knowledge) as well as the ability to obtain know how in handling their business (Winterton, 2002).

Even though the business owners might not need to deal directly with tools and equipment or might not need to undertake certain tasks by themselves, the knowledge and skills are necessary since they are the source of reference in the organization.

Personal competency: Personal competency refers to important personal qualities and abilities that help in building up personal strength and enhance an individual effectiveness in performing certain challenging tasks such as managing one own business (Man and Lau, 2000). This may include determination and self-belief (Thompson, 1996), emotional intelligence and self-awareness (Goleman, 1998), self-control and stress tolerance (Markman and Baron, 1998), self-motivation (Martin and Staines, 1994) as well as self-management (Winterton, 2002).

These competencies have strong linkage with personality traits and less directly observable (Bird, 1995), yet, they can be quite obvious from the way entrepreneurs deal with problems and challenging situations that they encounter in business. Possessing these competencies may assist entrepreneurs in building up their personal strengths to face challenges in handling their business.

\section{RESULTS AND DISCUSSION}

Conceptual framework: Based upon the contention that call researchers to focus on the contribution and ability of the business owners in generating successful ventures, a theoretical framework is developed to link entrepreneurial competencies and business success by taking into consideration the various roles held by entrepreneurs in managing their own business. This study generally proposed that entrepreneurs are engaged in three different roles including entrepreneurial role, managerial role and functional role.

Based upon the model of entrepreneurial competency proposed by Bird (1995) and by incorporating the content of entrepreneurial competencies developed by the existing studies (Ahmad and Seet, 2009; Chandler and Jansen, 1992; Martin and Staines, 1994; Man, 2001). A theoretical framework that integrates the various roles of entrepreneurs with competencies and business success in SMEs is advanced for consideration (Fig. 2). 
Int. Business Manage., 4 (2): 67-75, 2010

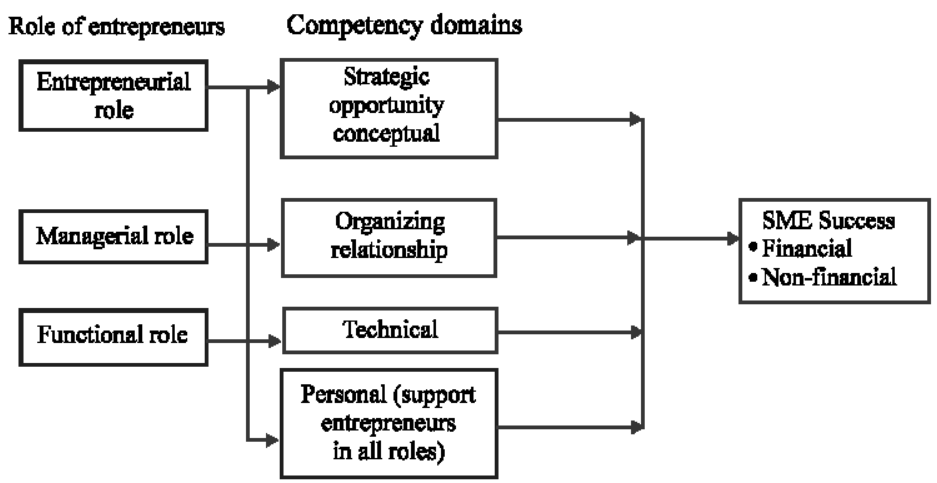

Fig. 2: Conceptual framework

Research propositions: This study argues that researchers should revisit the contribution of an individual entrepreneur in understanding the critical success factors of an SME. Since the competencies of the entrepreneurs reflect the quality of action taken by them that would enhance their effectiveness in managing the firms, it is strongly predicted that entrepreneurial competencies have direct impact on business success in SMEs. Specifically, traditional entrepreneurial role suggests that entrepreneurs are normally engaged in several major tasks including establishing long-term vision, formulating strategies, recognising and responding to opportunities taking risks and innovating (Chandler and Hanks, 1994). Various studies have endorsed that opportunity recognition and development is the heart of entrepreneurial activities (De Koning, 2003). In their efforts to explore and develop these opportunities, entrepreneurs act under the condition of uncertainty which require them to take risks.

As suggested in taking up these roles, entrepreneurs do not act blindfolded; they learn from their environment from previous mistakes they have made and also from other people (Smilor, 1997). Evidently, they do not simply take risk without considering the pros and cons of their decisions. Entrepreneurs evaluate and analyse risks in which mostly being conducted informally before making business-related judgments. Once decisions are made, entrepreneurs then commit themselves to achieve their goals and objectives. In order to achieve the goals and objectives, entrepreneurs need to combine productive resources and innovate new things or new way of doing things. In doing so, strong commitment on the part of entrepreneurs is essential since this commitment will keep them motivated to pursue their goals despite obstacles and hindrances impose by the environment. Synthesizing these arguments, engaging in entrepreneurial role requires entrepreneurs to prepare themselves with strategic, opportunity, conceptual, competencies to enable them increase the chances of their business success. It is therefore conjectured that:

Proposition 1: Engaging in entrepreneurial role, SME entrepreneurs require strategic, opportunity, commitment, conceptual competencies and these competencies are positively related to business success in SME. Entrepreneurs also take up tasks and activities that mirror managerial role. SMEs, considering its small nature, depend heavily on the owners to manage and organize the various activities relevant to the firms. Undertaking the managerial role also requires entrepreneurs to access various business resources including financial, human and other assets as well as organizing and mobilising those resources to maintain a viable venture.

The socio-cognitive approach to entrepreneurship suggest that to get access to various resources, entrepreneurs recognise the importance of establishing relationship, connections and networks (De Koning, 2003). In a sense, establishing good connections and contacts with the right people is seen as a useful means to overcome the shortage of resources in SMEs.

Also, given the difficulty in attracting skilled labours, energising teamwork is rather imperative. There is evidence to suggest that embracing teamwork is one of the means to gain competitive advantages (Longenecker et al., 1999). To strengthen teamwork, it requires a strong leadership on the part of entrepreneurs to create a good working climate where people are ready to work in team. Taken in concert, it is speculated that to lead a successful venture, entrepreneurs need to prepare themselves with organizing competency which involve managing and organizing the tangible and intangible resources and relationship competency which involve building and maintain relationship within and outside the organization. Therefore, it is proposed that: 
Proposition 2: Engaging in managerial role, SME entrepreneurs require organizing and relationship competencies and these competencies are positively related to business success in SME. The third role played by an entrepreneur is functional role. Performing this role requires specific grounding or background knowledge related to the business as well as expertise of using certain techniques or tool handling (Martin and Staines, 1994). Baum et al. (2001) maintain that entrepreneurs require a strong set of technical and industrial skill, besides organizing and opportunity recognition abilities.

Even though entrepreneurs may then employ more people to help in the businesses as they grow, it is essential for the entrepreneurs to have some basic knowhow on the areas related to their own field. This is because, technical or industry-related skill is seen as important sources of expert power that support the implementation of entrepreneur's vision and plan (Baum et al., 2001). Clearly, it is essential for the entrepreneurs to possess and master venture-specific skills to provide sustainable competitive advantage for their ventures. In view of this, it is contended that having engaged in functional role, entrepreneurs need to prepare themselves with technical competency to lead successful ventures. It is therefore predicted that:

Proposition 3: Engaging in functional role, SME entrepreneurs require technical competency and this competency is positively related to business success in SME.

Personal competency refers to the possession of personal qualities that will enhance the effectiveness of entrepreneurs (Man and Lau, 2000) is seen as an important competency area that support all the roles played by entrepreneurs. Successful entrepreneurs are often observed to possess high level of confidence and have tremendous amount of personal energy and drive and the capacity to work long hours (Timmons, 1978). They possess high level of determination and desire to overcomes hurdles solve the problems and continue to pursue their goals, which are often high and challenging but realistic and attainable. They are believed to be goal and action-oriented and possess high need for achievement (Blackman, 2003). It is therefore predicted that, personal competency would enhance the effectiveness of entrepreneurs in performing all roles which have positive implication on the business.

Proposition 4: Engaging in entrepreneurial, managerial and functional roles requires personal competency to support entrepreneurs in accomplishing various tasks and these personal competency is positively related to business success in SME.

\section{IMPLICATIONS}

This study offers theoretical and practical ramifications. Its theoretical contribution is grounded in conceptualising a model of entrepreneurs competencies by taking into consideration the various roles played by entrepreneurs in handling their own business. This study could contribute to the advancement of entrepreneurship development through the identification of important competencies. Practically, noting the radical changes in today's business environment, entrepreneurs are made aware of important competencies that may have causal connection to their business success.

It provides business owners with knowledge about the way they do business and to some extent helping them to be more conscious of their business and surroundings. The findings derived from this research may also be useful to entrepreneurs insofar as alerting them to the kind of training that may be necessary to improve their business performance. Finally, it is envisaged that this study may provide some useful guidelines for policy makers and educators as to ways in which educational programs might be improved to support the development and success of SMEs.

\section{CONCLUSION}

Entrepreneurs are believed to hold vital positions in the organization they have created. Through their decisions and actions, entrepreneurs pursue their business agenda that would ensure their survival and success in the industry. Their business vision and personal goals are also believed to affect the way they run their organization. Engaging in entrepreneurial role demands familiarity with the environment surrounding them to enable them recognise and spot high quality opportunities that will benefit their business.

In translating these opportunities into positive outcome, entrepreneurs are required to carefully manage their internal and external resources. Although some of the resources are readily available in the environment, it still depends on the ability of the entrepreneurs themselves to get access to those resources and mobilise them. Clearly, entrepreneurs in SMEs engage in complex tasks in operating successful ventures.

The complexity of tasks undertaken by entrepreneurs dictates that they need to prepare themselves with relevant competencies that could be utilised in developing a successful organization. In other words, it is important for entrepreneurs to equip themselves with relevant competencies that will eventually enhance their business performance. 


\section{REFERENCES}

Ahmad, N. and P.S. Seet, 2009. Understanding business success through the lens of SME founder-owners in Australia and Malaysia. Int. J. Entrepreneurial Ventur., 1: 72-87.

Barringer, B.R. and J.S. Harrison, 2000. Walking a tightrope: Creating value through interorganizational relationships. J. Manage., 26: 367-405.

Baum, J.R. and E.A. Locke, 2004. The relationship of entrepreneurial traits, skill and motivation to subsequent venture growth. J. Applied Psychol., 89: 587-598.

Baum, J.R., 1995. The Relation of Traits, Competencies, Motivation, Strategy and Structure to Venture Growth. In: Frontiers of Entrepreneurship Research, Bygrave, W.D., B.J. Bird, S. Birley, N.C. Churchill, M.G. Hay, R.H. Keeley and J.W.E. Wetzel (Eds.). Babson College, Wellesley, MA., pp: 547-561.

Baum, J.R., E.A. Locke and K.G. Smith, 2001. A multidimensional model of venture growth. Acad. Manage. J., 44: 292-303.

Beaver, G. and P. Jennings, 2005. Competitive advantage and entrepreneurial power: The dark side of entrepreneurship. J. Small Bus. Enterprise Dev., 12: 9-23.

Bird, B., 1995. Toward a Theory of Entrepreneurial Competency. In: Advances in Entrepreneurship, Firm Emergence and Growth, Katz, J.A. and R.H. Brockhaus (Eds.). Vol. 2, Jai Press Inc., Greenwich, Connecticut, pp: 51-72.

Blackman, A.J., 2003. Entrepreneurs: Interrelationship between their characteristics, values, expectations, management practices and SME performance. Doctoral Thesis, Griffith University, Gold Coast.

Chandler, G.N. and E. Jansen, 1992. The founder's selfassessed competence and venture performance. J. Bus. Ventur., 7: 223-236.

Chandler, G.N. and S.H. Hanks, 1994. Founder competence, the environment and venture performance. Entrepreneurship Theory. Practice, 18: $77-89$.

Choi, Y.R. and D.A. Shepherd, 2004. Entrepreneurs decisions to exploit opportunities. J. Manage., 30: 377-395.

De Koning, A., 2003. Opportunity Development: A SocioCognitive Perspective. In: Cognitive Approaches to Entrepreneurship Research: Advances in Entrepreneurship, Firm Emergence and Growth, Katz, J.A. and D.A. Shepherd (Eds.). Vol. 6, Jai Press Inc., Boulder, USA., pp: 265-314.
Edelman, L.F., C.B. Brush and T.S. Manolova, 2002. The impact of human and organizational resources on small firm strategy. J. Small Bus. Enterprise Dev., 9: $236-244$.

Gibb, A.A., 2005. The entrepreneur as the core competence of the firm: Implication for management educators. Entrepreneurship, Innovation and Small Business Network, No. 2.

Goleman, D., 1998. Working with Emotional Intelligence. Bantam Books, New York.

Hall, G. and S. Fulshaw, 1993. Factors associated with the Relative Performance Amongst Small Firms in the British Instrumentation Sector. In: Entrepreneurship and Business Development, Klnadt, H. (Ed.). Avebury, Hall and Hofer, Aldershot, pp: 227-237.

Hansen, E.L., 2001. Resource acquisition as a startup process: Initial stocks of social capital and organizational foundings. http:/www.babson.edu/ entrep/fer/IV/IVB/html/Iv-b.html.

Jenssen, J.I. and A. Greve, 2002. Does the degree of redundancy in social networks influence the success of business start-ups?. Int. J. Entrepreneurial Behav. Res., 8: 254-267.

Jenssen, J.I., 2001. Social networks, resources and entrepreneurship. Int. J. Entrepreneurship Innovat., 2: 103-109.

Longenecker, C.O., J.L. Simonetti and T.W. Sharkey, 1999. Why organizations fail: The view froma the front-line. Manage. Decision, 37: 503-513.

Man, T.W.Y. and T. Lau, 2000. Entrepreneurial competencies of SME owner/managers in the Hong Kong services sector: A qualitative analysis. J. Enterprising Cult., 8: 235-254.

Man, T.W.Y., 2001. Entrepreneurial competencies and the performance of small and medium enterprises in the Hong Kong services sector. Ph.D Thesis, Hong Kong Polytechnic University, Hong Kong.

Markman, G.D. and R.A. Baron, 1998. Social skills and entrepreneurs financial success: Evidence that the ability to get along with others really matters. Paper Presented at the Frontiers for Entrepreneurship Research.

Martin, G. and H. Staines, 1994. Managerial competences in small firms. J. Manage. Dev., 13: 23-34.

Masurel, E., K.V. Montfort and R. Lentink, 2003. SME innovation and the crucial role of the entrepreneur. Paper Presented at the Series Research Memoranda 0001, Free University Amsterdam, Faculty of Economics, Business Administration and Econometrics

McClelland, D.C., 1987. Characteristics of successful entrepreneurs. J. Creative Behav., 21: 219-233. 
Michalko, M., 2000. Thinking out of the box. http://www.winstonbrill.com/bri1001/html/article_in dex/articles/451-500/article472_body.html.

Mintzberg, H., 1973. The Nature of Managerial Work. Harper and Row, New York.

Parnell, J.A., D.L. Lester and M.L. Menefee, 2000. Strategy in response to organizational uncertainty: An alternative perspective. Manag. Decision, 38: $520-530$.

Ramsden, M. and R.J. Bennett, 2005. The benefits of external support to SMEs. J. Small Bus. Enterprise Dev., 125: 237-243.

Ritter, T. and H.G. Gemunden, 2004. The impact of a companys business strategy on its technological competence, network competence and innovation success. J. Bus. Res., 57: 548-556.

Shane, S. and S. Venkataraman, 2000. The promise of entrepreneurship as a field of research. Acad. Manage. Rev., 25: 217-226.

Smilor, R.W., 1997. Entrepreneurship: Reflections on aa subversive activity. J. Bus. Venturing, 12: 341-346.

Snell, R. and A. Lau, 1994. Exploring local competences salient for expanding small businesses. J. Manage., 13: 4-15.

Spencer, Jr. L.M. and S.M. Spencer, 1993. Competence at Work: Models for Superior Performance. John Wiley and Sons, New York.
Stonehouse, G. and J. Pemberton, 2002. Strategic planning in SMEs-some empirical findings. Manage. Decision, 40: 853-861.

Thompson, J., 1996. Strategic and competitive success: Towards a model of the comprehensively competent organization. Manage. Decision, 34: 5-19.

Thompson, J.L., 1999. The world of the entrepreneur-a naew perspective. J. Workplace Learning, 11: 209-224.

Thompson, J.L., R. Stuart and P.R. Lindsay, 1997. The competence of top team members: A framework for successful performance. Team Performance Manage., 3: 57-75.

Timmons, J.A., 1978. Characteristics and role demands of entrepreneurship. Am. J. Small Bus., 3: 5-17.

Tracy, B., 2005. The role of the entrepreneur. Entrepreneur Media Inc., USA. http:/www.entrepreneur.com/ startingabusiness/startupbasics/article 78478.html.

Wang, C.K. and B.L. Ang, 2004. Determinants of venture performance in Singapore. J. Small Bus. Manage., 42: 347-363.

Winterton, J., 2002. Entrepreneurship: Towards a competence framework for developing SME managers. United States Association for Small Business and Entrepreneurship.

Yu, T.F.L., 2001. Towards a capabilities perspective of the small firm. Int. J. Manage. Rev., 3: 185-197. 